\title{
Experimental studying of the drug efficiency Prostamax in the therapy of chronic aseptic prostatitis and its complications
}

\author{
Tatyana Gennadyevna Borovskaya $a^{1^{*}}$, Angelina Vladimirovna Pakhomova $^{1}$, \\ Anna Vladimirovna Vychuzhanina ${ }^{1}$, Marina Evgenyevna Poluektova ${ }^{1}$, \\ Tatyana Ivanovna Fomina ${ }^{1}$, Lubov Aexandrovna Ermolaeva ${ }^{1}$, Juliya Aexandrovna Schemerova ${ }^{1}$, \\ Oleg Konstantinovich Granstrem², Evgeniy Anatolyevich Neplochov ${ }^{3}$

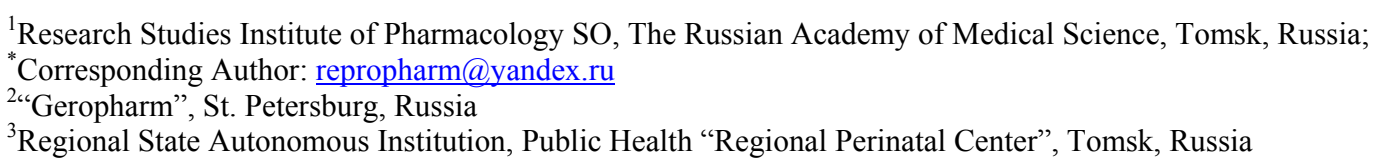

Received 30 April 2013; revised 30 May 2013; accepted 30 June 2013

Copyright (C) 2013 Tatyana Gennadyevna Borovskaya et al. This is an open access article distributed under the Creative Commons Attribution License, which permits unrestricted use, distribution, and reproduction in any medium, provided the original work is properly cited.

\begin{abstract}
The treatment of one of the most common urological diseases, a chronic aseptic prostatitis, is an exigeant problem. Used methods of pharmacotherapy are insufficiently effective and after treatment, as a rule, there comes a recrudescence. The efficiency of new prostatotropic agent Prostamax is studied in the present work, this drug is related to bioregulator peptides at experimental chronic aseptic inflammation of prostate gland. It is established that Prostamax reduces intensity of signs of a chronic inflammation (swelling, hyperemia of vessels, lymphoid infiltration), prevents development of sclerotic and atrophic processes. It is shown that the agent intensifies sexual activity of animals. Efficiency of the preparation Prostamax surpasses that among widespread prostatotropic agents derived from the extract of Serenoa repens and prostate of animals.
\end{abstract}

Keywords: Chronic Aseptic Prostatitis; Prostamax; Rats

\section{INTRODUCTION}

The inflammation of prostate gland (prostatitis) is the most common urological disease of men younger than 40 - 50 years [1]. Frequency of separate forms of a prostatitis, according to the literature, makes: an acute bacterial prostatitis $-5 \%-10 \%$, a chronic bacterial prostatitis $-6 \%$ - $10 \%$, a chronic abacterial prostatitis (CAP) or the chronic pelvic pain syndrome $-80 \%-90 \%[2,3]$. The most widespread type of prostatitis is CAP, which difficultly answer to a treatment. This disease has recurrent character and is accompanied by psychosomatic frustration, a neurosis, depression [4], essentially reduces life quality of patients. Disorders of copulative and reproductive functions refer to the number of its complications [5]. Now, the chronic prostatitis accompanies innocent hyperplasia of prostate gland of the elderly men whose number by the end of 20 century has increased more than in 3 times. Taking the foregoing into consideration, the problem of the disease treatment gets the increasing social importance. There are a great number of medical products in an arsenal of the CAP pharmacotherapy. The drugs, derived from the basis of extract Serenoa repens, refer to the number of the most popular prostatotropic means [6]. Along with them, the wide circulation was received by the medications created on the basis of the extracts of prostate. The last represent a complex of water-soluble biologically active peptides, derived from prostate of mature bulls $[7,8]$. Despite a great number of medical products, the prevalence of CAP has a tendency to increase, so impose the search of new prostatotropic medicines. Nowadays, the new drug Prostamax was created by the peptide synthesis method, and the medicinal agent also refers to bioregulatory pep-tides. This new tetrapeptide consisting of ly-syl-glutamyl-aspartyl-proline [patent RU(11) 2177802 (13) C1], which has productive tissue-specific effect on a prostate gland tissue. 
Results of experimental and clinical studying of bioregulatory peptides testify that they take direct part in processes of tissue-specific regulation of an expression of genes and biosynthesis [9]. Prostamax is derived with the help of a method of peptide synthesis, which is less lor-consuming in comparison with a way of drug creation process from a prostate extract. The work purpose is experimentally studying of the efficiency of the medication Prostamax in the therapy of chronic aseptic prostatitis and its complications, and also comparison of its efficiency to that of extracts of Serenoa repens and prostate.

\section{METHODS}

\subsection{Laboratory Animals}

The experiments were spent on 60 white rats-males of the Wistar population (weight of $330-500 \mathrm{~g}$, age of 4 months), 20 of which were composed the control and 10 - the baseline group. Animals had been received from the laboratory of biological modeling of the scientific research institute of pharmacology SO the Russian Academy of Medical Science, Tomsk (the certificate is available). The maintenance of rats was carried out in according with the rules accepted by the European convention of vertebrate animals protection, used for experimental and other scientific purposes (Strasbourg, 1986).

\subsection{Experimental Models}

Chronic aseptic inflammation of prostate gland had been caused by through-out suturing of its ventral share with the help of a silk thread [10].

\subsection{Compounds}

Operation was made under anesthesia with the use of thiopental sodium $(60 \mathrm{mg} / \mathrm{kg}$, intraperitoneal introduction). The two comparator agents were used in the experiment. The first-Prostamol Uno (Berlin-Chemie AG/ Menarini Group, Germany) is one of the most common medical products created on the basis of an extract of Serenoa repens [6,11-13]. The second-Samprost (OOO "Samson-Med", Russia) represents, also as well as Pros- tamax, bioregulatory peptide, the agent, which is created on the basis of an extract of prostate [14]. The experimental and comparator drugs had been administered to animals of study groups during 15 days, beginning with the 30th day after operation. The agents Prostamax and Samprost in a dose of $20 \mu \mathrm{g} / \mathrm{kg}$, intramuscularly. The drug Prostamol Uno had been administered to rats in a dose of $50 \mathrm{mg} / \mathrm{kg}$, intragastrically in form of $2.5 \%$ ethanol solution $[15,16]$. Animals of control groups $(n=20)$ were administered with drug solvents in the equivalent volume in the same period.

\subsection{Morphological Study}

In 45 days after operation, an euthanasia had been made to all study animals, and then, the stitched ventral share of prostate gland had been prepared. Defined its weight and volume, calculated weight factor and density. For histological research, they had taken the right (stitched) part of the front share of prostate gland (not less than 5 animals in each group) and fixed in a liquid of Karnua, filled in paraffin, prepared cuts in the thickness of $5 \mathrm{mi}-$ crons. Dewaxed cuts had been painted according to VanGizon on a connecting tissue. The area of epithelial structures, lumen of adenomeres and the area of collagenic fibers in the connecting-tissue interlayers had been measured on the standard area of a histological cut by means of the computer graphic analysis, and then, calculated a share of these indexes of the standard area of the cut.

\subsection{Statistics}

The received experimental data were processed statistically by means of nonparametric test of VilkoksonMann-Whitney and Fisher's angular transformation. Differences were considered significant at $\mathrm{P}<0.05$.

\section{RESULTS}

The results of quantitative evaluation of the study indexes are presented in the Tables $\mathbf{1}$ and 2 . It is necessary to underline that at preliminary comparison of values of all study indexes of control groups, it had been establish-

Table 1. The influence of the drug Prostamax on mass, volume, density of the ventral share of prostate gland of rats in the case of an chronic aseptic inflammation.

\begin{tabular}{|c|c|c|c|c|}
\hline Groups of animals & Mass of prostate, $\mathrm{mg}$ & Weight coefficient of prostate, $\mathrm{mg} / \mathrm{g}$ & Volume of prostate, $\mathrm{cm}^{3}$ & Density of prostate, $\mathrm{g} / \mathrm{cm}^{3}$ \\
\hline Background & $384.00 \pm 12.13$ & $0.83 \pm 0.03$ & $0.42 \pm 0.03$ & $0.92 \pm 0.02$ \\
\hline General control & $390.00 \pm 19.32$ & $0.78 \pm 0.08$ & $0.38 \pm 0.03$ & $1.05 \pm 0.01^{\#}$ \\
\hline Prostamax & $364.55 \pm 20.20$ & $0.83 \pm 0.06$ & $0.38 \pm 0.03$ & $0.98 \pm 0.02^{*}$ \\
\hline Samprost & $357.00 \pm 22.31$ & $0.82 \pm 0.05$ & $0.36 \pm 0.04$ & $0.99 \pm 0.02^{*}$ \\
\hline Prostamol Uno & $345.50 \pm 18.95$ & $0.77 \pm 0.05$ & $0.36 \pm 0.04$ & $0.96 \pm 0.02^{*}$ \\
\hline
\end{tabular}

Note: ${ }^{*}$ authentic differences with the control $\mathrm{P} \leq 0.05,{ }^{*}$ authentic differences with the background $\mathrm{P} \leq 0.05$. 
Table 2. The influence of the drug Prostamax on morphometric indexes of prostate gland of rats with a chronic prostatitis, \% of the standard area of a histological cut.

\begin{tabular}{cccc}
\hline Group & The area of collagenic fibres & The area of epithelium of acinuses & The luminal area of acinuses \\
\hline Background & $0.89 \pm 0.31$ & $25.48 \pm 3.23$ & $48.20 \pm 2.48$ \\
General control & $3.30 \pm 0.26^{\#}$ & $19.08 \pm 0.95^{\#}$ & $42.82 \pm 4.22$ \\
Prostamax & $1.25 \pm 0.25^{*}$ & $20.19 \pm 2.56$ & $45.53 \pm 4.45$ \\
Samprost & $1.12 \pm 0.12^{*}$ & $17.80 \pm 1.33^{\#}$ & $45.74 \pm 1.60$ \\
Prostamol Uno & $1.61 \pm 0.41^{*}$ & $16.90 \pm 1.09^{\#}$ & $52.74 \pm 2.20^{\#}$ \\
\hline
\end{tabular}

Note: ${ }^{*}$ authentic differences with the control $\mathrm{P} \leq 0.05$, ${ }^{*}$ authentic differences with the background $\mathrm{P} \leq 0.05$.

ed that they authentically did not differ from each other. Accordingly, controls had been united in the group of the "general" control (operation).

\subsection{Morphology}

At measuring of mass of the weight factor, the volume of the ventral share of prostate gland of animals, it had been established that almost all indexes, listed above in the control, authentically had not differed from baseline values in 45 days after operation (Table 1). The exception was made by such index as the density of gland which statistically significantly increased at animals in the control. In groups of animals, to which Prostamax and comparator agents had been administered, this index had been decreasing in comparison with the control and had not differed from the baseline values. The animals of groups Prostamax, Samprost and Prostamol Uno differences in terms of weight, a weight and prostate volume were not statistically significant with respect to the background and control.

\subsection{Morphometry}

The morphological analysis has shown that in 45 days after the experiment beginning in the control, signs of chronic aseptic inflammation of ventral share of prostate gland had been revealed. So, expansion and plethora of blood vessels was observed. Connecting-tissue interlayers between acinuses had appeared wider, than of background animals (Figures 1 and 2), both because of swelling and infiltration, and of the proliferation of collagenic fibers. It can cause increasing of density of the gland, noted above.

The rats, that had been administered with Prostamax against the operation, had hyperaemia and infiltration in the gland tissue, that had been expressed moderately, connecting-tissue interlayers had been expanded slightly in comparison with the background (Figure 3). The same effect had been revealed according to prostate gland of animals which had been administered with comparator agents. The quantitative morphological analysis has shown (Table 2) that the area of collagenic fibres had been increased in the control (in 3.9 times) in compari- son with the background that testifies about the presence of the expressed sclerosal process. The area of epithelium of adenomeres in the control had appeared to be lowered (up to $28 \%$ ) in comparison with that of thebackground rats. As the area of lumens of acinuses of the background and control animals had been the same, but the epithelium area reduction, inlaying adenomeres of prostate gland of rats of the control group, testifies to an atrophy of epithelium. The rats that had been administered with the agent Prostamax against the operation, had the area of collagenic fibres that had been decreased more than in 2.5 times in comparison with the control (Table 2). Comparator agents caused the similar effect in powers of intensity. The area of collagenic fibres against all used agents statistically significantly did not differ from that in the group of animals that had not been subjected to the operation (background). The obtained data testifies that Prostamax has ability, as well as comparator agents to detain development of sclerous processes. Earlier, it was noticed that in 45 days after the operation there were developing of atrophic processes in the ventral share of prostate gland, according to the reduction of the area of the epithelium of acinuses. The animals that had been administered with Prostamol Uno and Samprost, had this indicator also lowered, in comparison with the animals that had not been subjected to the operation, so

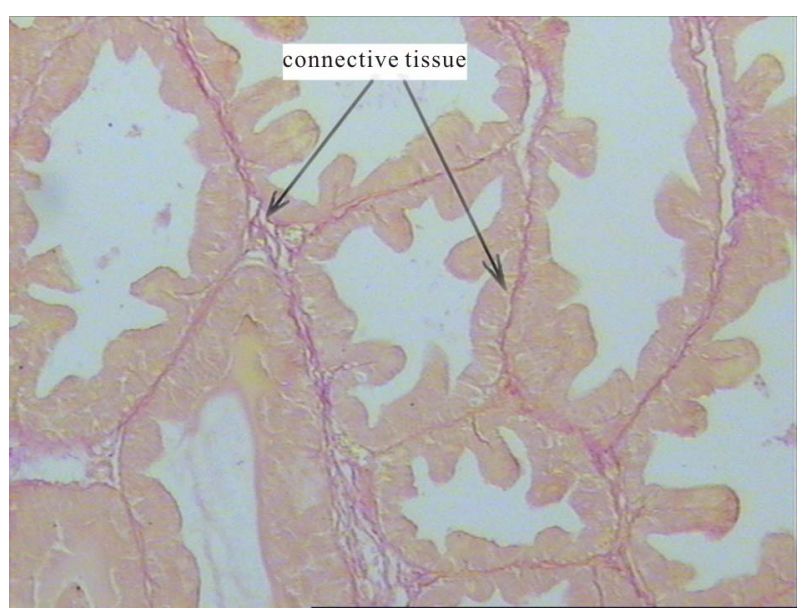

Figure 1. Side proportion of the prostate intact rats. Colouring picrofuchsin. $\times 200$. 


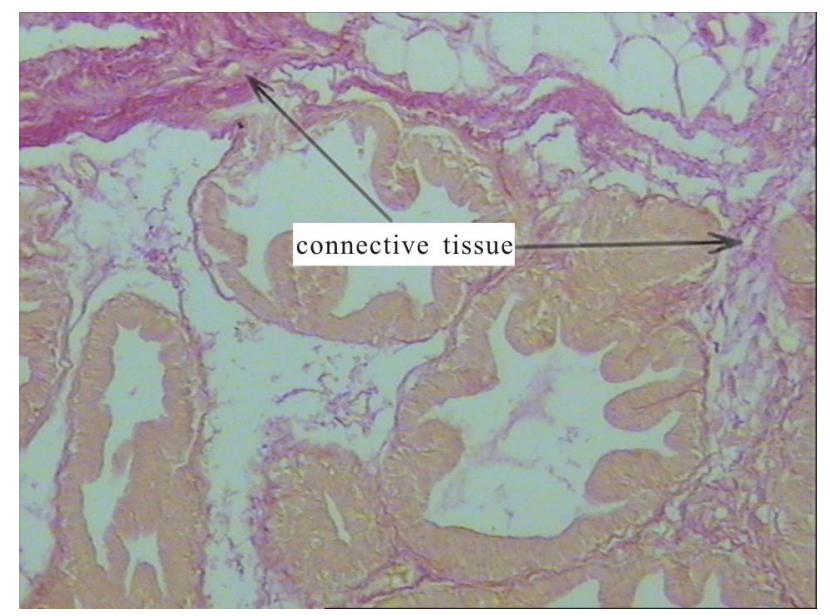

Figure 2. Side proportion of the prostate abacterial rats with chronic prostatitis (control). Increasing the amount of collagen fibers. Colouring picrofuchsin. $\times 200$.

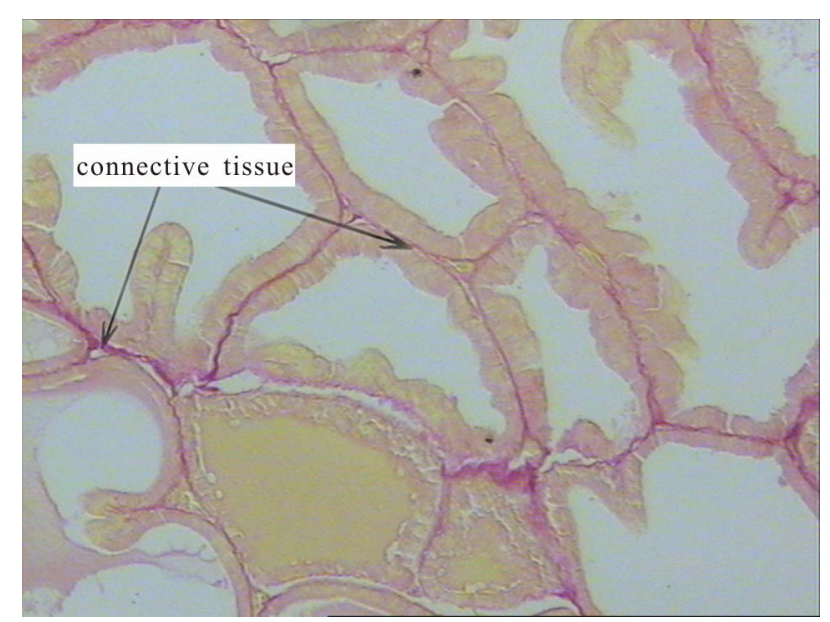

Figure 3. Side proportion of the prostate rats with chronic prostatitis abacterial receiving Prostamaks. Reducing the amount of collagen fibers as compared to the control. Colouring picrofuchsin. $\times 200$.

that testifies that against its administration, the development of atrophic processes is not prevented, and moreover, the tendency of its increasing is revealed. The noted effects of Prostamol Uno and Samprost can be associated with the ones that had been revealed earlier [17], antiproliferative properties of the agent. During the measuring of the area of epithelium of acinuses in the ventral share of prostate of the animals that had been administered with Prostamax against the operation, it has been established that this indicator statistically significantly did not differ from that of the animals that had not been subjected to the operation. So, that allows concluding, that the drug has ability to block the development of atrophic processes. The lumen area of acinuses has been appeared similar almost in all compared groups. The exception was made by the group of animals that had been admin- istered with Prostamol Uno, the lumen area acinuses in which, had been exceeded baseline values. It can be result of considerable reduction of the epithelium area of acinuses (Table 2).

\section{CONCLUSION}

Within 45 days after through-out suturing of the ventral share of prostate gland of rats with a silk thread, there was developing of signs of chronic aseptic inflammations in it: swelling, hyperaemia of vessels, lymphoid infiltration of stroma, the atrophy, a sclerosis, the gland density had been increasing. The Prostamax administration reduced swelling intensity, hyperaemia, and cellular infiltration, blocked the development of sclerosal processes. The same effects, similar according to the degree of manifestation, were also observed against the administration with the comparator agents. At the same time, comparator agents, unlike Prostamax, did not prevent development of atrophic processes, so that allows speaking about its greater efficiency in the case of an experimental chronic abacterial prostatitis.

\section{REFERENCES}

[1] Krieger, J.N., Lee, S.W., Jeon, J., Cheah, P.Y., et al. (2008) Epidemiology of prostatitis. International Journal of Antimicrobial Agents, 31, 85-90.

doi:10.1016/j.ijantimicag.2007.08.028

[2] Batstone, G.R. and Doble, A. (2003) Chronic prostatitis. Current Opinion in Urology, 13, 23-29. doi:10.1097/00042307-200301000-00005

[3] Krieger, J.N., Nyberg, L.J. and Nickel, J.C. (1999) NIH consensus definition and classification of prostatitis. JAMA, 282, 236-237. doi:10.1001/jama.282.3.236

[4] Wenninger, K., Heiman, J.R., Rothman, I., Berghuis, J.P. and Berger, R.E. (1996) Sickness impact of chronic nonbacterial prostatitis and its correlates. Journal of Urology, 155, 965-968. doi:10.1016/S0022-5347(01)66359-6

[5] Iunda, I.F. and Varvashenia, V.V. (1993) Sexual disorders in patients with prostatic adenoma combined with chronic prostatitis and without. Lik Sprava, 10-12, 47-51.

[6] Lowe, F.C. and Ku, J.C. (1996) Phytotherapy in treatment of bening prostatic hyperplasia: A critical review. Urology, 48, 12-20. doi:10.1016/S0090-4295(96)00077-5

[7] Gorpichenko, I.I. and Boyko, N.I. (1993) Administration of the peptidic bioregulator-Prostatilen in the sexological and urological practice. Andrology Reproduction Sexology, 2, 4-7.

[8] Kamalov, A.A. and Dorofeev, S.D. (2003) The modern views according to the problem of chronic prostatitis. Russian Medical Journal, 11, 229-233.

[9] Havinson, V.H. and Malinin, V.V. (2008) Heroprotective effect of peptides in the case of health disorders due to ecological factors. Reporter of the Russian Military Medical Academy Appendix, 2-3, 472. 
[10] Borovskaya, T.G., Fomina, T.I. and Loskutova, O.P. (2002) Antibodies to a prostatic specific antigene in over small doses: Influence on a morphological and functional conditions of prostate gland of rats. Bulletin of Experimental Biology and Medicine, A, 104-106.

[11] Bayne, C.W., Ross, M., Donnelly, F. and Habib, F.K. (2000) The selectivity and specificity of the actions of the lipido-sterolic extract of Serenoa repens (Permixon) on the prostate. Journal of Urology (Baltimore), 164, 876881.

[12] Reissigl, A., Pointner, J., Djavan, B., et al. (2003) Multi centre study to evaluate the safety and efficacy of phytotherapeuticum Permixon in the treatment of chronic prostatitis/chronic pelvic pain syndrome. Materials of 18th EAU Meeting, Madrid, 49.

[13] Vela-Navarrete, R., Garcia-Cardoso, J., Barat, A., Manzerbeitia, F., et al. (2002) Effects of the lipido sterolic extract of Serenoa repens (Permixon) on infiltrating cells and inflammatory markers in prostatic tissues from $\mathrm{BPH}$ patients. Materials of 17th EAU Meeting, Birmingham, A-238.
[14] Tkachuk, V.N., Al-Shukri, S.K. and Lotsan-Medvedev, A.K. (2006) Vitaprost efficacy in patients with chronic abacterial prostatitis. Urologia, 2, 71-75.

[15] Mitropoulos, D., Kyroudi, A., Zervas, A. et al. (2002). In vivo effect of the lipido-sterolic extract of Serenoa repens (Permixon) on mast cell accumulation and glandular epithelium trophism in the rat prostate. World Journal of Urology, 19, 457-461.

[16] Saveleva, K.V., Borovskaya, T.G., Hejfets, I.A., et al. (2007) Comparative estimation of pharmacological activity Afala on model harmone productive inflammations of prostate at rats. Bulletin of Experimental Biology and Medicine, 144, 542-544.

[17] Sivkov, A.V., Oshchepkov, V.N. and Medvedev, A.M. (2005) Diseases of prostate gland. The first results of the administration of lipidic sterolic extract of Serenoa repens of patients with chronic abacterial prostatitis. Consilium Medicum, 7.

http://www.consilium-medicum.com/medicum/article/129 $32 /$ 